\title{
Pendidikan Kontrasepsi Pada Wanita Pasangan Usia Subur Sebagai Upaya Antisipasi Baby Bomming Di Masa Adaptasi Kebiasaan Baru Pasca Pandemi Covid-19 Di Wilayah Kecamatan Kuta Utara
}

\author{
Ni Made Rai Widiastuti*, Kadek Widiantari \\ Kebidanan Politeknik Kesehatan Kartini Bali \\ *Email : raiwidiastuti@gmail.com
}

\begin{abstract}
The results of family planning services during the COVID-19 pandemic in national scale has decreased in the number of contraceptive uses reaching 40\% in almost all regions in Indonesia (BKKBN, 2020). This could be caused by various problems, including an increase in the number of unwanted pregnancies and baby booms or increase of birth rate. This is due to the obstruction of access to services, delaying access to health facilities due to fears of contracting COVID-19 and increasing of husband and wife sexual intercourse without using contraceptives that inducing pregnancy. Based on the results of Widiastuti's research in 2020, where a survey was conducted to find out the description of family planning use during the pandemic in the North Kuta District, it was found that half of them (53.2\%) of respondents were using contraceptives and almost half of them (46.8\%) of respondents did not use contraception. One of the efforts to suppress the surge in baby births is through the Family Planning program for couples of childbearing age. The aim of this community service is to provide knowledge about contraceptive tools and methods in suppressing the surge in baby births. The targets are women of childbearing age aged 15-45 years who have not used contraception or who use and do not make repeat visits as many as 30 people. The implementation of the activity was carried out by assessing the level of understanding of the respondents by pre-testing through google forms, implementing counseling, family planning counseling and introduction of contraceptives and evaluating the material by post-testing via google forms. The results of the activity show that there is an increase in mother's knowledge about family planning tools and methods, which is expected to influence the behavior of woman in using contraceptives so that they are expected to anticipate the occurrence of baby boom.
\end{abstract}

Keywords: women of childbearing age, contraception, COVID-19 pandemic, baby boom

\begin{abstract}
Abstrak
Hasil pelayanan komtrasepsi secara Nasional pada masa pandemi COVID-19 terjadi penurunan angka penggunaan alat kontrasepsi yang mencapai $40 \%$ dan ini terjadi hampir diseluruh Provinsi di Indonesia (BKKBN, 2020). Keadaan ini dapat menimbulkan masalah yang salah satunya dapat meningkatkan angka kelahiran (baby boom) dan kehamilan yang tidak diinginkan (unwanted pregnancy). Hal ini dikarenakan terbatasnya akses kepelayanan kesehatan, WUS menunda datang ke fasilitas kesehatan oleh karena khawatir tertular COVID-19 dan aktifitas hubungan suami istri tanpa menggunakan alat kontrasepsi yang dapat beresiko terjadinya kehamilan. Berdasarkan hasil penelitian Widiastuti tahun 2020, dimana survey telah dilakukan untuk mengatahui gambaran pemakaian KB pada masa pandemi di wilayah Kecamatan Kuta Utara. Hasil penelitian tersebut didapatkan setengahnya yaitu 53,2\% responden sedang menggunakan alat kontrasepsi dan hampir setengahnya yaitu 46,8\% responden tidak menggunakan alat kontrasepsi. Salah satu upaya menekan lonjakan kelahiran bayi dengan melalui program Keluarga Berencana terhadap pasangan usia subur. Tujuan dari pengabdian masyarakat ini adalah untuk memberi pengetahuan tentang alat dan metode kontrasepsi dalam menekan lonjakan kelahiran bayi. Sasarannya adalah wanita pasangan usia subur berusia 15 - 45 tahun yang belum menggunakan kontrasepsi atau yang menggunakan dan tidak melakukan kunjungan ulang sebanyak 30 orang. Pelaksanaan kegiatan dilakukan dengan mengkaji tingkat pemahaman responden dengan pre test melalui google formulir, pelaksanaan penyuluhan, konseling KB dan pengenalan alat kontrasepsi dan mengevaluasi materi dengan post test melalui google formulir. Hasil kegiatan menunjukkan terjadi peningkatan pengetahuan ibu tentang alat dan metode KB, diharapkan dapat mempengaruhi perilaku ibu dalam penggunaan alat kontrasepsi sehingga diharapkan dapat mengatisipasi terjadinya baby bomming.
\end{abstract}

Kata kunci : wanita usia subur, kontrasepsi, pandemic COVID-19, baby booms 


\section{PENDAhuluan}

Dunia saat ini sedang mengalami kasus pandemi Virus COVID-19, yang telah menginfeksi secara global ke 200 negara termasuk wilayah Indonesia. Pada tanggal 31 Desember 2019 World Health Organization (WHO) menyatakan terdapat kasus jenis pneumonia dengan penyebab yang tidak jelas terjadi di Kota Wuhan, Provinsi Hubei, China. Kasus kejadian penyakit ini berkembang hingga terdapat laporan adanya kematian yang terjadi. Pada tanggal 30 Januari 2020, WHO menetapkan dengan tegas bahwa COVID-19 sebagai Public Health Emergency of International Concern (PHEIC) atau Kedaruratan Kesehatan Masyarakat Yang Meresahkan Dunia (KKMMD).

Kejadian COVID-19 di Indonesia telah dilaporkan pada tanggal 11 Maret 2020 dengan adanya dua (2) kasus konfirmasi positif COVID-19. Tidak dapat dipungkiri, kejadian kasus COVID-19 di Indonesia terus bertambah dari hari ke hari. Hal ini mengakibatkan kepanikan diseluruh lapisan masyarakat dan dan mempengaruhi seluruh sektor kerja salah satunya pada pemakaian alat kontrasepsi. Program Pembangunan Keluarga, Kependudukan dan Keluarga Berencana (Banggakencana) harus tetap dilaksanakan oleh masyarakat dengan tetap menaati protokol kesehatan (BKKBN, 2020). BKKBN tahun 2020 melaporkan terjadi penurunan pemakaian alat kontrasepsi hampir 40\% dan terjadi diseluruh provinsi di Indonesia. Hal ini dapat mengakibatkan terjadinya kehamilan tidak diinginkan (KTD) dan peningkatan jumlah kelahiran (baby booms) (BKKBN, 2020).

Hal ini diindikasikan oleh karena pasangan usia subur (PUS) yang seharusnya mengakses fasilitas kesehatan namun menunda untuk datang oleh karena khawatir tertular COVID-19 dan terjadi peningkatan hubungan suami istri tanpa menggunakan alat kontrasepsi akibat dirumah saja. Dengan adanya permasalahan ini mengakibatkan lonjakan kelahiran bayi atau yang disebut Baby Booms (Widayati, 2020). Berdaasarkan hasil penelitian Widiastuti tahun 2020, dimana survey telah dilakukan untuk mengetahui gambaran pemakaian alat kontrasepsi pada masa pandemi di wilayah Kecamatan Kuta Utara, didapatkan bahwa setengahnya yaitu 53,2\% responden sedang menggunakan alat kontrasepsi dan hampir setengahnya yaitu 46,8\% responden tidak menggunakan alat kontrasepsi. Tujuan pendampingan Wanita PUS adalah untuk meningkatkan pengetahuan dalam menggunkaan alat kontrasepsi sehingga pengetahuan yang baik dapat membentuk prilaku positif terhadap pemakaian kontrasepsi sehingga dampak Baby Booms dapat ditekan.

\section{METODE}

Pengabdian kepada masyarakat dilakukan dari bulan Juli sampai Agustus 2021. Lokasi pengamas di Kecamatan Kuta Utara. Sasarannya adalah wanita pasangan usia subur berusia $15-45$ tahun tidak sedang menggunakan kontrasepsi dan tidak melakukan kunjungan ulang selama masa adaptasi kebiasaan baru pasca pandemic COVID-19 sebanyak 30 orang dimana berkomunikasi dengan respoden melaui media Whatssapp.

Tahapan pelaksanaan dibagi ke dalam tiga tahapan yaitu tahap pertama adalah mengkaji tingkat pemahaman responden dengan membagikan kuesioner ( pre test), tahap kedua dilakukan penyuluhan dengan memberikan materi tentang kontrasepsi dan dilanjutkan dengan konseling. Tahap terakhir dilakukan evaluasi dan feedback terhadap materi yang telah disampaikan sebagai upaya untuk meningkatkan pengetahuan. Selanjutnya dilihat perbandingan data dalam bentuk persentase dari hasil kuesioner pre test dan post test.

\section{HASIL DAN PEMBAHASAN}

Tabel 1. Distribusi Pengetahuan Wanita Usia Subur tentang Metode Kontrasepsi (n=30)

\begin{tabular}{ccccc}
\hline Pengetahuan & F & $\%$ & F & $\%$ \\
& Sebelum & $\%$ & Sesudah & $\%$ \\
\hline Baik & 7 & 23,3 & 24 & 80 \\
Cukup & 8 & 26,7 & 4 & 13,3 \\
Kurang & 15 & 50 & 2 & 6,7 \\
\hline
\end{tabular}


Tabel 1 diatas menunjukkan bahwa setengahnya (50\%) memiliki pengetahuan yang kurang sebelum diberikan pemaparan dan konseling tentang metode kontrasepsi. Setelah diberikan materi didapatkan bahwa sebagian besar yaitu $80 \%$ mengalami peningkatan pengetahuan menjadi kategori baik.

Akseptor yang memiliki pengetahuan baik tentang program $\mathrm{KB}$, akan mempengaruhi dalam keputusan memilih metode kontrasepsi yang akan digunakan dengan mempertimbangkan kecocokan, efeksamping, keamanan dan kenyamanan. Serta memilih tempat pelayanan kesehatan yang cocok, sehingga kesadaran akan tetap tinggi untuk terus memanfaatkan pelayanan kesehatan salah satunya dalam pelayanan kontrasepsi (Nainggolan., 2020).

Berbagai faktor yang dapat mempengaruhi pengetahuan seseorang yaitu tingkat pendidikan, dimana semakin tinggi pendidikan seseorang maka diharapkan semakin banyak pula informasi yang diketahuinya. Pendidikan yang telah dikuasai akan sangat membantu dalam bertindak dan bagaimana bisa mencari solusi dan memecahkan masalah hidup yang dijalankan. Pendidikan tinggi yang didapatkan akan membantu dalam bertindak secara rasional, sehingga akan lebih mudah menerima ide atau gagasan yang baru. Berbagai sumber informasi yang didapatkan juga dapat mempengaruhi tingkat pengetahuan seseorang, oleh karena jika akseptor tersebut mendapatkan berbagai macam sumber informasi, maka semakin banyak pula informasi yang diketahui. Faktor sosial budaya dan ekonomi serta lingkungan juga dapat berpengaruh terhadap tingkat pengetahuan akseptor. Berbagai pengalaman yang telah dilalui juga mempengaruhi pengetahuan seseorang, dimana semakin banyak pengalamannya maka semakin banyak pula pengetahuannya (Herawati, et al, 2020).

Pengetahuan pada masing-masing individu dapat mempengaruhi perilaku ibu dalam memilih kontrasepsi. Akseptor dengan pengetahuan kurang akan cendrung kurang tepat dalam memilih kontrasepsi. Pengetahuan akseptor tentang alat kontrasepsi sangat dibutuhkan, agar alat kontrasepsi yang akan digunakan tepat dan sesuai kebutuhan. Beberapa hal yang perlu diketahui akseptor tentang alat kontrasepsi yaitu tujuan penggunaan alat kontrasepsi, jenis-jenis atau metode alat kontrasepsi, efek samping masing-masing alat kontrasepsi, kontraindikasi masing-masing alat kontrasepsi, keuntungan dan kerugian masing-masing alat kontrasepsi, serta proses kembalinya masa subur (Sumarroh, 2015).

Pada kondisi pandemi saat ini, sangat diharapkan pasangan usia subur, terutama PUS dengan 4 Terlalu (4T) yaitu terlalu muda, terlalu tua, terlalu banyak, terlalu dekat, diharapkan dapat menunda kehamilan dengan tetap menggunakan alat kontrasepsi. Untuk itu, dalam pelayanan kontrasepsi pada masa pandemi COVID 19 ini, pelayanan harus tetap dilakukan dengan memperhatikan protokol kesehatan dengan prinsip pencegahan pengendalian infeksi dan physical distancing.

\section{KESIMPULAN}

Pelaksanaan pendampingan pada wanita pasangan usia subur sebagai upaya menekan jumlah kelahiran dan antisipaasi terjdinya baby booms pasca pandemi, dengan pemberian edukasi dan informasi pentingnya keikutsertaan dalam program KB bagi wanita pasangan usia subur. Pendampingan dengan media daring yaitu whatssapp sangat bermanfaat sebagai wadah untuk menyebarkan informasi dan menjadi lebih mudah dengan biaya yang lebih murah. Saran diharapkan dari Kecamatan melakukan penyuluhan melalui daring atau media sosial seperti whatssapp dan Instagram Kecamatan.

\section{UCAPAN TERIMAKASIH}

Tim pelaksana ingin mengucapkan terima kasih kepada LPPM Politeknik Kesehatan Kartini Bali dan Yayasan Kartini Bali sebagai penyandang dana melalui skema hibah PKM dosen internal tahun 2021. Penulis juga mengucapkan terimakasih kepada Kecamatan Kuta Utara yang memberikan ijin dan membantu dalam pelaksanaan, serta masyarakat yang berpartisipasi dalam mengikuti kegiatan ini dan semua pihak yang ikut dalam kegiatan PKM ini.

\section{DAFTAR PUSTAKA}

Alami, Triarsy, et al. "Hubungan Persepsi Akseptor Kb Dengan Pemilihan Mkjp Di Kelurahan Tahtul Yaman Kota Jambi Tahun 2017." Jurnal Ilmiah PANNMED (Pharmacist, Analyst, Nurse, Nutrition, Midwivery, Environment, Dentist), vol. 14, no. 2, 2019, pp. 9-16, 
doi:10.36911/pannmed.v14i2.539.

Aprillia, Yuna Trisuci, et al. "Analisis Penggunaan Alat Kontrasepsi Sebelum Dan Saat Pandemi Covid19.” Jurnal Untuk Masyarakat Sehat (JUKMAS), vol. 4, no. 2, 2020, pp. 190-200.

Aslam, F. (2020). COVID-19 and Importance of Social Distancing. Preprints, 30(1), 1-6. https://doi.org/10.20944/preprints202004.0078.v1

Dina Fitriana Rosyada, Rita Dian Pratiwi, E. N. W. (2020). Family Planning Services by Midwifery of Private Midwifery Practice in Yogyakarta During the Pandemic Period of Covid-19. Jurnal Ilmu Kesehatan Masyarakat, 11(July), 123-135

Lora Ekana Nainggolan., et al. (2020). Belajar dari Covid-19: Perspektif Ekonomi \& Kesehatan (1st ed.). Yayasan Kita Menulis. Megaria Purba, Endang Budiati, A. D. (2020). Determinan Perilaku yang Berhubungan dengan Terjadinya Unmet Need KB pada Pasangan Usia Subur (PUS) di Kota Bandar Lampung. Malahayati Nursing Journal, 2, 491-504.

Nurjasmi, E. (2020). Situasi Pelayanan Kebidanan pada Masa Pandemi COVID-19 dan Memasuki Era New-Normal. https://www.ibi.or.id/media/Materi Webinar IBI - USAID Jalin Covid19/Seri 5 10 Juni 2020/PDF 1 Emi 10 Juni USAID Jalin SITUASI PELAYANAN KB PADA MASA PANDEMI COVID-19 \%26 ERA NEW NORMAL -compressed.pdf

Purwanti, S. (2021). Dampak Penurunan Jumlah Kunjungan KB terhadap Ancaman Baby Boom di Era Covid-19. Jurnal Bina Cipta Husada, XVI(2). Sumarroh, Z. (2015). Hubungan Tingkat Pengetahuan, Sikap dengan Pelaksanaan Konseling Awal Kontrasepsi oleh Bidan pada Pasangan Usia Subur (PUS) di Puskesmas Kota Yogyakarta. In Biomass Chem Eng (Vol. 49, Issues 23-6).

Kemenkes RI, BKKBN. "Panduan Pelayanan Keluarga Berencana Dan Kesehatan Reproduksi Dalam Situasi Pandemi COVID-19.” Kemenkes RI, 2020, p. 5.

Widayati, D. (2020). Fenomena Baby Boom dan Pengangguran di Masa Pandemi Covid- 19. Https://Www.Kompasiana.Com/Diana24933/5f95904bd541df7e241013c2/Fenomena -BabyBoom-Dan-Pengangguran-Di-Masa-Pandemi-Covid-19.

Witono, S. P. (2020). Kepesertaan Keluarga Berencana Pada Masa Awal Pandemi Covid- 19 di Daerah Istimewa Yogyakarta. Jurnal Kependudukan Dan Keluarga Berencana. 